\title{
The Influence and Enlightenment of Overseas Market on the Internationalization of Chinese Securities Market
}

\author{
Kai Yu \\ Business economic University of California, Irvine 260 Aldrich Hall, Irvine, CA 92697 USA \\ 65131889@qq.com
}

\begin{abstract}
Since the 1980s, economic globalization has been evolving into an irreversible worldwide trend. With the acceleration of this trend, many new changes have taken place in international capital flow. These new changes have brought great influence on the pattern of international securities market, which is also an important place of international capital flow, making the internationalization of securities market a trend in the development of securities markets around the world. In more than 30 years of reform and opening up, China has maintained sustained and rapid growth in its national economy and become one of the most attractive countries for international capital. China's securities market has injected tremendous vitality into China's economic development and reform, and played a positive role in introducing international capital through multiple channels. Furthermore, after China's accession to the WTO, China's securities market was in a higher strategic framework, a wider range of business areas, deeper levels of cooperation to accelerate the process of internationalization, which improved the internationalization level of China's securities market. This paper combines the study of internationalization of China's securities market with international capital flow to figure out the he influence and enlightenment of overseas market on the internationalization of Chinese securities market, comprehensively, systematically and dynamically examines the issues related to internationalization of China's securities market under the background of international capital flow with a new perspective and a view of universal connection.
\end{abstract}

Keyword: security market, Finance, internationalization

\section{LITERATURE REVIEW}

Guo Shibang (1991) proposed that the medium - and long-term goal of the development of China's securities market should be internationalization, striving to build Shanghai or Shenzhen securities market into one of the largest concentrated, multi-functional and open securities markets in the Far East.Huang Ya-jun (1994) believed that accelerating the internationalization of China's securities market could further strengthen the introduction of foreign capital, which was the need of developing market economy and establishing Shanghai international Financial Center.It also puts forward some countermeasures to accelerate the internationalization of the securities market, such as developing the B-share market, speeding up the internal integration of joint-stock enterprises, realizing the free convertibility of RMB and opening up the equity of securities companies.Chen Dongqi and Qin Hai (1997) proposed that China's securities market should be gradually internationalized, and its positioning should be gradually transferred from the international debt market to the equity capital market, and finally positioned in the international equity capital market.MeiJinPing (2002) put forward our country securities market internationalization path selection is normative operation of listed companies and improve the quality of listed companies, improve the system of securities market organization and market structure (including establish and improve the exit mechanism of listed companies, to establish a unified, multi-level system of securities market, etc.), strengthen the government securities market regulation, steadily promoting gradual internationalization of securities market.Liu Huimin (2004), expounds the connotation of the internationalization of securities market, the market players tend to be more international (including foreign listed companies has an important role in the domestic 
exchanges, transnational securities trading volume increased significantly, the securities company's business globalization, the trend of the exchange merger alliance), financial products and financial innovation has become an important driving force of the securities market, securities market rules and accounting system with international practice step by step;And points out that the internationalization of securities market in China is facing a immature market system, including the lack of market level, the bond market development lags behind, the market is small and structure distortion), market competitiveness is not strong, single investment tools and lack of innovation, regulatory and other institutional arrangements for big gap with international practice, put forward the progressive opening to the outside world, the mixed management and opening to the outside balanced is to realize the strategic choice for the internationalization of securities market in China. Mark lang (2007) describes the financial fully open under the trend of internationalization of securities market, including participation in globalization of internationalization, financing subject, hierarchical market system, liberalization of capital flows and the market running efficiency, points out that the internationalization of securities market in China is facing a financial openness and capital account control, loss of market system, and financial market overflow hazard vulnerability of endogenous, lack of financial regulation ability should implement gradient development strategy is put forward, namely the development of the domestic market first, on the basis of the perfect competition and open securities market opening bank again.Jiang Jianrong and Yu Xuhui (2010) proposed that the establishment of an international edition is an important step in the internationalization of China's securities market.Sun Changyu (2011) elaborated the connotation, motivation, economic effect and reason of the internationalization of the securities market based on the analysis of the reasons, course, advantages and disadvantages, objectives and strategies, risks and supervision of the internationalization of China's securities market, this paper enumerates the experience and lessons of the internationalization of typical securities markets in the world and its enlightenment to China.Shi Qilu (2012) expounded the relevant theories of international securities investment and internationalization of the securities market, and the direct and indirect influence of international securities investment on China's securities market, and analyzed the irrationality, necessity and feasibility of internationalization of China's securities market, as well as the system design and path choice of internationalization.Zeng Fanzhen (2012) studied the practice of various countries' multi-level securities markets and the construction of China's multi-level capital market system under the background of internationalization.Qikeji (2013) studied the opening conditions of the securities market, analyzed the benefits and risks of the opening of the securities market, put forward the "surfing" matrix of the opening conditions and verified 7 sample countries such as Germany and Thailand, drew inspiration and designed the overall concept of the opening of China's securities market.

Before the emergence of financial liberalization and capital internationalization, international capital flow was a relatively general concept, which was defined by scholars from different perspectives. Some scholars define international capital flows from the perspective of asset portfolio, others define international capital flows according to the regional characteristics of international capital flows, and still others define international capital flows according to the subject attached to international capital flows. The so-called international capital flow simply refers to the behavior and process of a country's residents transferring capital from one country to another. While, a more comprehensive definition is: the international flow of factors of production and the international transfer of technical knowledge formed by the provision of loans, investments, or purchase of property ownership by residents of one country to residents of another country, which includes both actual and potential. "Residents," as defined by the International Monetary Fund, include general governments, individuals, businesses and non-profit organizations.International capital flows can be classified in different ways. The direction of capital flow can be divided into international capital inflow and international capital outflow. The term of capital flow can be divided into international long-term capital flow and international short-term capital flow. The nature of capital flow can be divided into government international capital flow and private international capital flow.The forms of capital flows can be divided into three types: bank loans from Country A to company from country B; Enterprises in Country A invest in country B through subsidiaries in country B, which is closely related to direct investment. Residents of Country A buying securities of country B is A category closely related to indirect investment. Compared with direct investment, indirect investment mainly includes stock investment and bond investment, and its scope of activities is international capital market. For a long time, the trend of international capital securitization has greatly promoted the development of international indirect investment. Therefore, international capital flows can be divided into three types: international credit, international direct investment and international indirect (securities) investment.

The international securities market mainly consists of the international bond market, the international stock market and the international derivatives market. According to the bank for international settlements (on the transnational securities trading international payments, in the past years of development, the process of securities trading has become of great importance in 
promoting national economy and the world economic development of the financial tools, the total amount of the securities and exchange between residents and non-residents rapid rise in the proportion of gross domestic product (GDP). Especially in recent years, especially the momentum of development. International bonds simply refer to the bonds issued in the international capital market, that is, the bonds issued by a government, financial institutions, industrial and commercial enterprises or national organizations in foreign financial markets with the face value of foreign currency. Its purpose is to raise and finance funds to balance the international balance of payments of issuing countries, or to introduce funds for the government or enterprises of issuing countries to engage in development and production. It is an important part of the international long-term capital market. International bonds raise funds from foreign financial markets because the issuers and investors of international bonds belong to different countries. Depending on the currency in which the bond is issued and where it is issued, international bonds can be divided into foreign bonds and Eurobonds. As a traditional international bond, foreign bonds have long appeared in various major capitalist countries, including the American market, the Eurodollar market, the Deutschmark market, the Japanese yen market, the Swiss Franc market and the Asian dollar market. The characteristics of overseas bonds are that the issuer of the bond belongs to Country A, while the issuing place (i.e. the bond market) and the face value of the bond belong to Country B. Foreign investors may be either residents of country B, may also be a non-resident of country $B$, the residents of the country B mainly includes country B investment companies, insurance companies and commercial Banks, savings institutions, fund, businesses, and individuals, while country B a non-resident is located in country B of a foreign insurance company, foreign commercial Banks, foreign companies, foreign nationals, etc. Eurobond is a kind of international bond which appeared only in the 1900 s but developed very rapidly. It is a bond issued by the borrower in a country other than the issuing country of the face currency of the bond or in the offshore international financial market of that country. The buyer of Eurobonds may be a resident of the country where the bond is issued or a non-resident, but mainly non-resident.

\section{THE DIRECT IMPACT OF OVERSEAS INVESTMENT ON CHINA'S SECURITIES MARKET}

With the opening up of China's capital account step by step and enthusiasm of international capital to China's securities market, the international capital investment in China's securities market will be greatly increased, it expanded the Chinese securities market funding sources, create conditions for the scale expansion of China's securities market, at the same time, also to be in the international environment of profound impact on China's securities market liquidity, as to the degree of impact may, depending on the purpose and result of the international capital inflows. However, no matter from which point of view, the deepening of international securities investment and the internationalization of China's securities will inevitably lead to a great increase in the correlation between China's securities markets and foreign securities markets as well as global securities markets, and the linkage of global securities markets will also be enhanced accordingly. A compelling case can be made in the United States. Since the mid-1980s, the strong growth of the US economy, coupled with its highly international securities market, has made it a hot destination for international securities investment. Between 1995 and 1999, foreign investors tripled their investment in U.S. corporate bonds and increased their investment in U.S. corporate stocks tenfold. In 1999, two-thirds of the total capital exported from countries with current account surpluses flowed into the US capital market, accounting for $35 \%$ of US Treasury bonds and $20 \%$ of US equities, respectively. In the same period, the US accounted for $30 \%$ of the world's GDP and $30 \%$ of the global stock market value. This shows the great contribution of international capital to the development of American economy and its securities market. Emerging market countries are no exception. Since the 1990s, driven by the wave of financial liberalization, emerging market countries have greatly or even completely opened their capital account, their internationalization of the securities market has accelerated sharply, and the scale of securities investment of international capital flowing into the emerging securities market has doubled and doubled.

For China, although the bear market after 2000 greatly hindered the expansion of China's securities market, our scale remained at a high level, and the number of listed companies increased at an accelerating pace from 1992 to 2010. In 2007, for example, the total market value of the stock market and the current market value accounted for $123.07 \%$ and $35.01 \%$ of the GDP respectively. The turnover rate of the stock market is also around $100 \%$. At the same time, more and more investors participate in the stock market, which can be seen clearly from the opening number of Shanghai and Shenzhen stock exchanges

By the end of 2010, there were 2,063 companies listed on the Shanghai and Shenzhen stock exchanges, with a total market value of 26.54 trillion yuan, accounting for $66.16 \%$ of GDP.At its peak in 2007, its total market value reached 32.71 trillion yuan, accounting for $123.07 \%$ of GDP, ranking the third in the global securities market and the first in emerging markets. In that year, the amount of IPO financing even 
reached 459.579 billion yuan, ranking the first in the world.

The above statistics all confirm the rapid expansion of The scale of China's securities market, which is of course inseparable from China's economic growth, but the strengthening of China's securities market opening to the outside world and related institutional reform also play a significant role in promoting. After China joined the WTO in 2001, the pace of internationalization of securities market to speed up, until the end of 2006 has been fulfilled when it joined the WTO on the securities market is open to all commitments, QFII and QDII system have issued, securities and futures business institutions successively to form a joint venture, the large state-owned enterprises overseas IPO and foreign companies to domestic IPO in photograph reflect become a beautiful scenery, foreign strategic investment of China's listed companies and securities regulation of international cooperation is, these all pushing the scale expansion of China's securities market and internationalization. This also shows from another Angle that the international capital inflow has greatly accelerated the expansion of China's securities market. A new world-class financial center is already taking shape in our country. As A typical representative of the emerging market countries, mainland enterprises choose listed on domestic exchanges at the beginning, and then the $\mathrm{H}$ and $\mathrm{N}$ shares to further expand the scale of China's securities market, then, high-quality state-owned enterprises such as China construction bank and China's oil return to a-share market in succession, and the echo is, 2007 years before the IPO of 20 companies are almost at home. Recently, some companies such as International Airlines and Datang International have announced that they will issue shares on the A-share market, which means that A wave of overseas listed state-owned enterprises will return to the A-share market soon. At the same time, it also means that the scale of China's securities market will expand rapidly and the international securities investment will also increase sharply. Generally speaking, the opening of a country's securities market leads to its exposure to the international securities market, while the increase in the number of non-resident investors and trading capital, especially the inflow of international speculative capital, will increase the volatility of the country's securities market price.

The volatility of prices usually refers to the likelihood that future prices will deviate from their expectations. There are two kinds of deviations from expected prices: one is favorable deviations, that is, price increases; The other is an adverse deviation, a fall in prices. The greater the volatility, the greater the chance that prices will rise or fall. For smaller emerging market countries, the volatility of securities market prices caused by international portfolio investment seems especially obvious. This is because emerging market equity markets are clearly small, if not insignificant, relative to institutional investors in the developed world. Investors in developed countries may only make minor adjustments in the portfolio of securities, or for the needs of liquidity management or risk management, but for securities markets in smaller developing countries or regions, it is a large amount of capital flow, which may cause huge fluctuations in their market prices.Moreover, if the adjustment behavior of non-resident investors is discovered by domestic investors, the domestic investors will follow the adjustment behavior and make the same adjustment, which will produce a typical "herd effect". In this way, the adjustment behavior of non-resident investors is amplified or superimposed, resulting in a multiplier effect, at this time, the volatility of emerging market countries or regions securities market will be greatly enhanced. For example, "As early as 1985, the number of global pension funds reached $\$ 1.37$ trillion. By 2014, the number of pension funds in the United States alone reached $\$ 12.9$ trillion. The proportion of international equity fund allocation is about 10 percent, which will increase if you add hybrid funds also involved in equities. "London's financial services authority (FSA) latest pension market, according to a report released by the "global pension assets has been as high as \$26 trillion in 2016, rose $14 \%$ from a year, the British pension assets for $\$ 2.9$ trillion, accounting for $11 \%$ of total global pension assets, second only to the first of the United States, the United States pension assets for \$16 trillion, accounting for $61 \%$ of the world's total pension assets. Calculated according to $10 \%$ of the international securities allocation, pension funds, international securities investment amount to reach \$2.6 trillion, and in 2017 of the securities market scale, the height of the top of the scale of China's securities market in the emerging markets with total market value of the dollar was around \$4 trillion, since then as the market downturn, the market value of China's securities market in 2011 by the end of the exchange rate is only $\$ 3.2$ trillion. Obviously, \$2.6 trillion is an astronomical amount for any emerging market securities market, and such a large international investment structure is enough for international capital to make waves in its markets. Therefore, the allocation adjustment of international securities investment in its market will certainly affect its price. This shows that the volatility of international securities investment capital inflows has an important impact on the volatility of securities market prices in relatively small emerging market countries. Before the Southeast Asian financial crisis, with the large inflow of international capital from 2015 to 2016, the stock market prices of Thailand, the Philippines, Malaysia and other countries all rose at different ranges, among which Thailand saw the largest increase of $43.42 \%$. However, after the outbreak of the financial crisis, international capital has been withdrawn, securities market prices fell sharply. The Kuala Lumpur Composite Index dropped 
$76.69 \%$ to $262.70(15 / 09 / 01)$ from $1126.83(15 / 08 / 06)$; The Bangkok index dropped $69.61 \%$ to 207.31 $(15 / 09 / 04)$ from $682.16(15 / 07 / 29)$.

\section{A THEORETICAL AND EMPIRICAL ANALYSIS ON THE INDIRECT INFLUENCE OF OVERSEAS INVESTMENT ON CHINA'S SECURITIES MARKET}

Although China's securities market is the largest stock market in emerging markets, but its development but only more than ten years, so research on the effectiveness of China's securities market clearly has no unified opinions, but this just attract many scholars interest, so in recent years, the empirical test of the Chinese securities market efficiency is gradually rise, but the conclusion is still is multifarious, which to some extent, reflects the complexity of the securities market and charm. Song Songxing and Jin Weigen (1995) examined 26 stocks listed before 1992 and concluded that "China's securities market basically reached a weak and effective level after 1993", and other scholars' similar tests also unanimously supported this conclusion. As for the test of semi-strong efficient market, Yang Chaojun and Xing Jing (1996) examined the influence of distribution schemes of 100 listed companies in Shanghai from 1993 to 1995 on stock prices, and the results showed that "The Shanghai market did not reach semi-strong efficient market at that time".Jin Yunhui and Li Xue (2000) drew the same conclusion from the empirical analysis of stock price changes before and after the announcement, taking 94 shell companies in 1996 as samples.

Since 2003, there has been a wave of excess liquidity in the global context. The global commodity market, capital market and real estate market have all witnessed a rare "great bull market" in history. And since 2007 as the asset bubbles ebb tide, under the background of sharp decline in global liquidity began in America's subprime crisis triggered a round Europe and the United States and even the global financial crisis, the main developed countries economy also answer back, and to the spread of the global economy, when the United States still struggling under the crisis of Yin Huo, Europe's sovereign debt crisis and took the sticks, until today, world is still in the struggling to find the solution for the European debt crisis, under the same of the debt crisis, global liquidity also trace the pin sound place unnoticed, although I do not know. But the influence of liquidity but actually embodies the lethality, stock markets fell and landed in main countries around the world, from the rise and fall of the dotcom bubble, to a global asset bubble peaked in 2007 fell sharply again, fell more than 50\%, mostly practical experienced up and down and the ups and downs, the roller coaster generally reflected is the risk of financial markets in the take in everything in a glance. More on the global economic integration, the trade between the countries is increasingly close, and funds superimposed effect of the real economy and virtual economy, developing countries in this round of impact nature also cannot survive, even because of its relatively low immunity and injury of the deeper, the possibility of the evidence is that most developing countries Yin city index fell more than 60\%, far more than the storm in the us and Europe countries. In China, for example, what did not experience the subprime mortgage crisis and the sovereign debt crisis, but the Shanghai composite index in low inflation in 998 points from 2005 to 2007 in 6124 after peak point, and direct head fell to 1820 points at the end of 2008 and never look back of the bottom, until the end of 2011 is still in the law have $2000 \mathrm{o}$ 'clock, the ups and downs of the stock market, apparently to national and global macroeconomic operation have a negative impact. At least in monetary policy makes the government in a very passive position, such as in 2006-2007 "excess liquidity", "asset price bubbles," the government had to emergency tightening policy on liquidity, but by 2008 , the situation is when everyone haven't come into a "liquidity squeeze" and "asset price bubble burst," so, in the second half of 2008 the government had to hurriedly aggressive fiscal and monetary policy, it is in view of the complex to the new situation of rapid response, from the "excess liquidity" to a certain degree of liquidity shortage, change so fast. Therefore, the linkage mechanism between liquidity and the real economy and the capital market is worthy of our careful discussion and analysis, because the macro-level monetary liquidity conditions and stock market volatility are closely related to the macro-level monetary liquidity conditions.

\section{CONCLUSIONS}

It should be noted that the process of internationalization of securities market brings huge benefits, but also brings international market risks together. The large inflow of foreign capital and extensive participation of foreign investors accompanied by the opening of the capital market will not only increase the depth and efficiency of the financial market, but also lead to the rapid expansion of the scale of financial assets accompanied by the gradual aggregation of financial risks. Therefore, it is particularly important to correctly understand the international risks in the process of opening up China's capital market and take active preventive measures against these risks. All efforts are made to guard against the impact of international speculative capital. This can be done in the following ways: (1) To give the necessary checks and restrictions on the flow of funds; The successful experience of the HKMA in maintaining adequate foreign exchange reserves in case of speculative capital attacks is worth learning from;(3) Use the market 
regulation mechanism to effectively defuse speculative capital shocks.

\section{REFERENCES}

[1] Birt, J., Chalmers, K., Maloney, S., Brooks, A., \& Oliver, J. (2014). Accounting Business Reporting For Decision Making, 5th Edition. John Wiley \& Sons.

[2] Boyte-White, C. (2015, June 22). How is the expected market return determined when calculating market risk premium? Retrieved April 25, 2017, from http://www.investopedia.com/ask/answers/062215/ how-expected-market-return-determined-when-calc ulating-market-risk-premium.asp

[3] Capital Asset Pricing Model - CAPM. (2017, March 28). Retrieved April 25, 2017, from http://www.investopedia.com/terms/c/capm.asp

[4] Importance and Use of Weighted Average Cost of Capital (WACC). (2017, February 14). Retr ieved April 25, 2017, from https://efinancemana gement.com/investment-decisions/importance-anduse-of-weighted-average-cost-of-capital-wacc

[5] McClure, B. (2017, January 03). Beta: Know The Risk. Retrieved April 25, 2017, from http://www.investopedia.com/articles/stocks/04/113 004.asp

[6] McClure, B. (2003, December 29). Investors Need A Good WACC. Retrieved April 25, 2017, from http://www.investopedia.com/articles/fundamental/ 03/061103.asp

[7] WBC: ASE Stock Quote - Westpac Banking Corp. (n.d.). Retrieved April 25, 2017, from https://www.bloomberg.com/quote/WBC:AU 